\title{
Eurytoma robusta (Hymenoptera: Eurytomidae), a local key factor in the population dynamics of Urophora cardui (Diptera: Tephritidae): a comparative analysis
}

\author{
HeLmut ZWÖLFER ${ }^{1}$, MARC BÖHEIM ${ }^{2}$ and ERwIN BECK ${ }^{2}$ \\ ${ }^{1}$ University of Bayreuth, c/o Department of Animal Ecology I, Universitäts-Str., D-95440 Bayreuth, Germany; \\ e-mail: helmut.zwoelfer@uni-bayreuth.de \\ ${ }^{2}$ Department of Plant Physiology, e-mail: erwin.beck@uni-bayreuth.de
}

Key words. Hymenoptera, Eurytomidae, Diptera, Tephritidae, entomophytophagy, superparasitism, gall ecology, local host specialisation, population dynamics, Eurytoma robusta, Urophora cardui

\begin{abstract}
Eurytoma robusta Mayr (Chalcidoidea) exploits host galls either as a primary or secondary parasitoid, an entomophytophagous inquiline or occasionally even as a predator. We present data on its ecology and impact on gall densities and population trends of the gall fly Urophora cardui (L.) on Cirsium arvense (L.) Scop. Habitat preference, host gall selection, clutch size, and high incidence of superparasitism causing empty gall cells show that E. robusta, a generalist with a broad host spectrum, is relatively poorly adapted to parasitising U. cardui. The influence of E. robusta on U. cardui in the Belfort-Sundgau region (1970-2004), in the Upper Rhine Valley (1973-2004) and in north-eastern Bavaria (1977-2004), differed considerably. In the forests of the Upper Rhine Valley and the Belfort-Sundgau region, where U. cardui has relatively stable source-sink populations, E. robusta is present but not the dominant mortality factor of the gall fly. In most areas of north-eastern Bavaria $U$. cardui occurs in fragmented populations and short lived non-equilibrium metapopulations. In these systems E. robusta became more abundant over the last five years, which resulted in a high incidence of superparasitism, an increase in the number of empty gall cells and reduced gall quality. The greatly increased degree of parasitism and an excess of empty cells resulted recently in the collapse of most local populations of $U$. cardui in the study area south of Bayreuth (north-eastern Bavaria). Together with earlier records the data presented here suggest that in northeastern Bavaria E. robusta cause fluctuations in the abundance of $U$. cardui, which have a periodicity of 5-7 years. A remarkable feature of the oligophagous $E$. robusta is its high fidelity to formerly abundant $U$. cardui populations, which, with declining host densities, leads to overexploitation, resulting in a high incidence of superparasitism and high larval mortality. The possible influence of the habitat structure on the effect of $E$. robusta on the population dynamics of $U$. cardui is discussed. Our data plus that of other authors suggest that, with regard to U. cardui, E. robusta can develop a temporary local host specialisation.
\end{abstract}

\section{INTRODUCTION}

The Thistle Gall Fly, Urophora cardui (L.), is a highly specialized gall former, which attacks the Creeping Thistle, Cirsium arvense (L.) Scop., and 2 closely related species. Field populations of $U$. cardui have been monitored in the Belfort-Sundgau region (eastern France) (Zwölfer, 1979, 1994), in the Upper Rhine Valley (Zwölfer, 1994; Schlumprecht, 1990) and in north-east Bavaria (Eber \& Brandl, 1994, 1996, 2003, and this study). Particularly in north-east Bavaria, U. cardui is subject to pronounced fluctuations in abundance. Patches of $U$. cardui develop in areas formerly not occupied, flourish, and then, within a few years, usually decline synchronously. The recent (2004/5) collapse of the great majority of the $U$. cardui populations we were monitoring south of Bayreuth (Bavaria) prompted a search for the causative factors and in particular the study of Eurytoma robusta Mayr, which is the only larval mortality factor potentially capable of causing local extinctions of $U$. cardui.

In this study the data on the host range of E. robusta are summarized and the features of its biology and ecology that may influence the population dynamics of $U$. cardui discussed. The cyclical fluctuations of $U$. cardui populations in the study area south of Bayreuth are described as the influence of E. robusta is much stronger there than in regions with more stable $U$. cardui populations. Our findings are discussed in relation to those on the population ecology of $U$. cardui (Schlumprecht, 1990; Eber \& Brandl, 1994, 2003; Johannesen \& Seitz, 2003a,b; Vikberg, 2005). A detailed account on the biology of $E$. robusta will be published elsewhere (Zwölfer et al., in prep.).

\section{MATERIAL AND METHODS}

An assessment of the presence and population density of $U$. cardui is easy, as its galls occur in our study areas only on the main and lateral shoots of $C$. arvense, where they can be monitored from August/September until April/May. As U. cardui galls usually occur as metapopulations or in fragmented populations, a pragmatic sampling procedure was adopted. Wherever galls were found on groups of thistles, which were at least 200 $\mathrm{m}$ apart from the next thistle patch, they were treated as a sample, i.e. a population or subpopulation. We analysed gall data collected between 1980 and 2005 in the Bayreuth area at an altitude of 370-580 m above sea level and compared it with that collected between 1972 and 2005 in the Sundgau-Belfort area (eastern France) at altitudes of 300-500 m and floodplain forests of the Upper Rhine Valley (region between Karlsruhe and Breisach) at altitudes of $120-180 \mathrm{~m}$. Altogether 13790 galls from 722 samples were evaluated. 
At 32 localities in the Bayreuth area (Fig. 1) the presence of galls and gall densities were monitored annually from 1995 to 2005. Except for 2 sites, with less than 200 thistle shoots, only C. arvense populations with at least 200 (and up to 5000) thistle shoots (ramets) were chosen. Excluding a site, which was destroyed by road construction, and another, where $C$. arvense was out competed by woody vegetation, all thistle populations persisted from at least 1995 to 2005 . Due to the heterogeneous structure of most thistle patches and the high variance of parasitism within patches, it was not possible to analyse galls on a square meter basis. To assess gall density a simple density index of the numbers of galls $/ 100 C$. arvense shoots was calculated. Additionally a log density index, which is described by Zwölfer (1994), was used.

Assessing the mortality of $U$. cardui requires invasive procedures, i.e. the dissection of galls, which can affect the local density of $U$. cardui and its parasitoids. We tried to reduce this effect by taking small random samples from the larger gall populations, leaving every year the majority of the small gall patches untouched. This procedure was justified as in our study area most local patches of $U$. cardui formed parts of a fragmented (and connected) population system rather than a true metapopulation, which is characterized by each patch exhibiting independent population dynamics. To obtain data on the oviposition and larval development of E. robusta immature galls were collected and dissected in the second half of August, i.e. shortly after oviposition and hatching of the larvae of the parasitoid. Due to the often high rate of superparasitism and larval mortality, clutch sizes of E. robusta were assessed by direct counts of empty egg shells. SPSS/PC +4.0 was employed for data storage and statistical tests. Nonparametric tests were used, if the data points were not normally distributed or if the variances failed the test of homogeneity.

\section{RESULTS}

\section{Host range of $E$. robusta}

As Eurytoma robusta is a morphospecies, the wide host range reported in the literature may actually be because it consists of a number of sibling species. According to Claridge (1961) E. robusta attacks a wide range of Tephritid galls on Cardueae host plants. Zwölfer \& ArnoldRinehart (1993) record the morphospecies E. robusta from 14 Palearctic Urophora spp. on 22 species of Cardueae. E. robusta is recorded attacking $U$. cardui on $C$. arvense in England (Claridge, 1961), Denmark (Johannesen \& Seitz, 2003a), Finland (Vikberg, 2005), France, Switzerland, northern Italy, Germany, Austria, Poland and Slovakia (Zwölfer, pers. records). In northern Greece it attacks $U$. cardui larvae in galls on Cirsium creticum (Zwölfer, unpubl.) and in the Ural mountains Frenzel et al. (2000) found E. robusta in U. cardui galls on C. setosum.

\section{Superparasitism by E. robusta and the empty cell phenomenon}

There was a highly significant $(\mathrm{n}=408, \mathrm{p}<0.001)$ but only weak $(\mathrm{r}=0.357)$ positive correlation between clutch size and the number of surviving E. robusta larvae/gall. The comparison between egg shells/gall and number of surviving E. robusta larvae (Fig. 2) demonstrates a high rate of superparasitism, i.e. of mortality occurring between oviposition and the development of the firstinstar larva of the parasitoid. Counting the numbers of

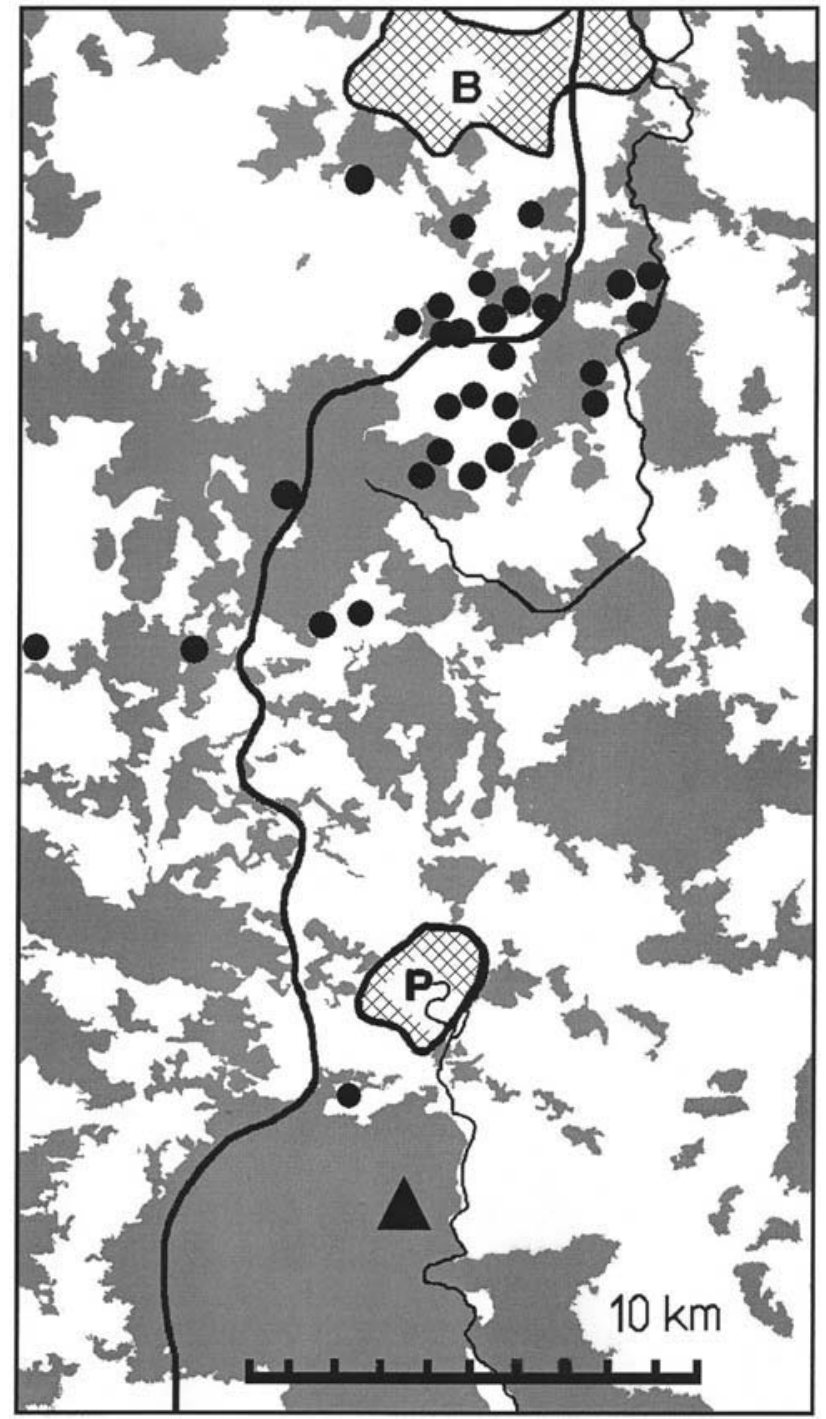

Fig. 1. The study area south of Bayreuth: $\mathrm{B}=$ Bayreuth, $\mathrm{P}=$ Pegnitz. Shaded areas $=$ forests. Black circles $=$ thistles stands monitored for U. cardui from 1995 to 2005 . The largely synchronous development of these short-lived $U$. cardui subpopulations suggests that they are parts of a fragmented population system rather than a metapopulation. Black triangle $=$ an isolated, large and relatively stable $U$. cardui population system in a clearing of the Veldenstein forest, monitored since 1979.

empty egg shells and living larvae in 347 successfully attacked galls originating from France, Austria and Germany, an average of $4.77 \pm 4.33$ egg shells per gall (mean and s.e.) were found with a minimum of 1 and a maximum of 31 , but only $0.90 \pm 1.10$ living larvae (minimum 0, maximum 5), which indicates an overall mortality of about $80 \%$.

When a second-instar larva of $U$. cardui dies or is killed after the initiation of a gall, but before it starts growing and feeding on the secondary nutritive tissues (Lalonde \& Shorthouse, 1984), its chamber remains small and empty. Such empty cells occurred in galls of $86.7 \%$ (i.e. in 834 out of 962) of the gall samples analysed by us during the last 35 years. The average frequency of empty cells/gall/sample varies greatly between regions and 


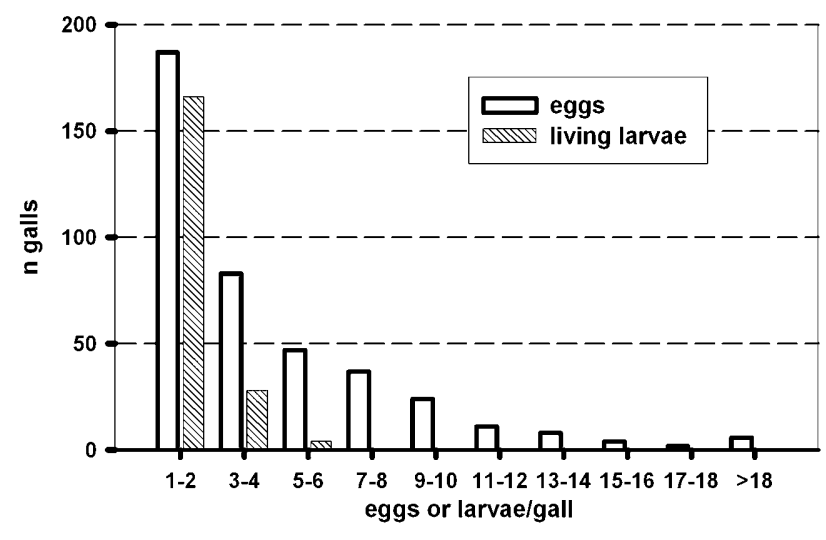

Fig. 2. Frequency distribution of egg shells and living larvae of E. robusta in 409 galls of $U$. cardui (origin eastern France, southern Germany, eastern Austria). 211 of these galls contained empty egg shells but no E. robusta larvae.

within a region between individual years (Fig. 3). An ANOVA gives an $\mathrm{F}$ value for the regions ( $\mathrm{df} 1)$ of 46.1 (p $<0.001)$, for the years (df 8) of $16.3(\mathrm{p}<0.001)$ and for the interaction of regions and years of $8.2(\mathrm{p}<0.001)$. In the case where all the $U$. cardui larvae in a gall are killed and the E. robusta larvae are unable to develop, normal growth of the gall does not occur. Galls that contain only empty cells, do not lignify. They consist of a relatively soft, grey-brown cork-like tissue. Empty cells were observed in galls at an altitude of $800 \mathrm{~m}$ (Fichtelgebirge), where low temperatures apparently killed the young larvae. As a rule, however, empty cells result from attack by larvae of $E$. robusta, which is indicated by the presence of empty egg shells. In Canada, where E. robusta does not occur and parasitism of the introduced U. cardui is minimal, empty cells are not recorded (Peschken \& Derby, 1997). Galls with many E. robusta eggs often contain only empty cells or E. robusta larvae, which after hibernation are too small (body length $\leq 2 \mathrm{~mm}$ ) to produce viable adults. Also poor synchronisation of E. robusta attack with gall development may result in increased larval mortality and a high incidence of empty cells. This

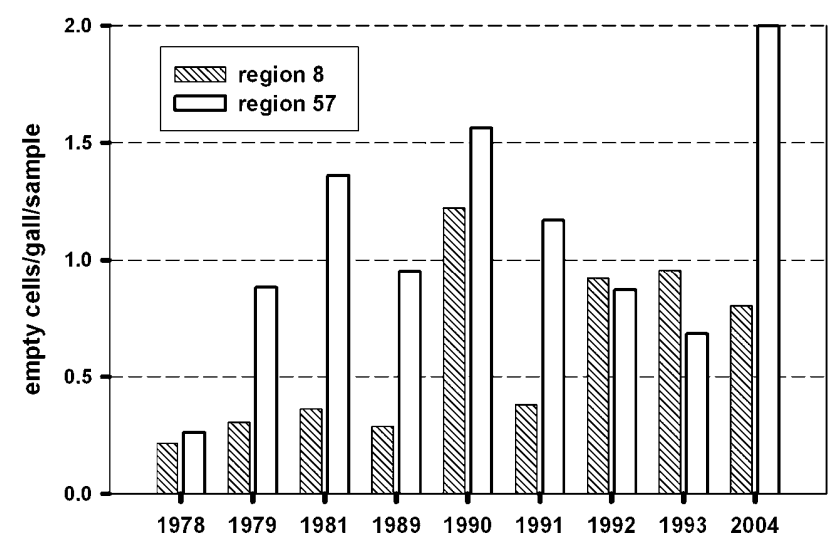

Fig. 3. Average number of empty cells/gall/ sample from the Belfort-Sundgau region (region $=8$ ) (total of 251 samples and 5419 galls) and the study area south of Bayreuth (region $=75$ ) (total of 72 samples and 1654 galls).

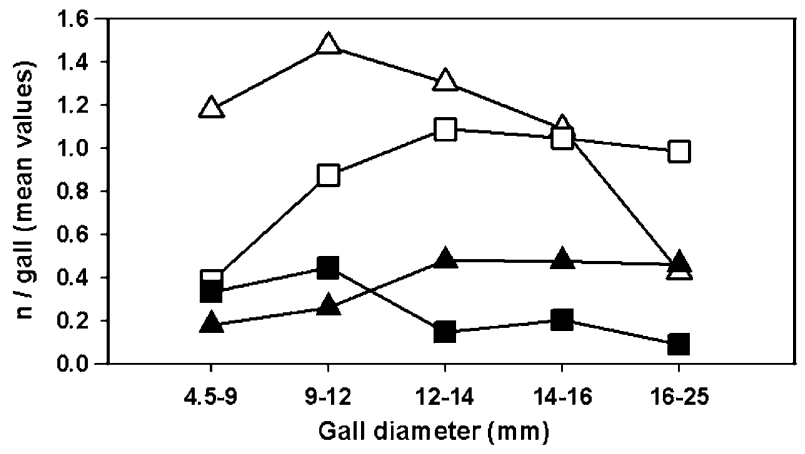

Fig. 4a. The relationships between the average number of empty cells/gall (triangles), number of surviving E. robusta larvae/gall (squares) and gall diameter, in the Bayreuth (open symbols) and Belfort-Sundgau regions (filled symbols).

interpretation is corroborated by a sample of galls $(\mathrm{n}=$ 100) from the study area south of Bayreuth (Veldensteiner Forst, 27 August 2003), in which the content of early formed terminal galls and later formed side-shoot and axil galls was separately examined: Empty cells were significantly more frequent in later produced galls $\left(\chi^{2}=\right.$ 26.89 , df $1, \mathrm{p}<0.001$ ), in which the $U$. cardui larvae were very young at the time of the attack by E. robusta. Schlumprecht (1990), too, records the lowest incidence of empty cells in terminal shoot galls. When the numbers of both egg shells and surviving E. robusta larvae were compared, a significant positive correlation between the clutch size/gall and the occurrence of empty cells (Spearman correlation $\mathrm{r}_{\mathrm{s}}=0.256, \mathrm{n}=176, \mathrm{p}=0.0006$ ) and a negative correlation between surviving $E$. robusta larvae and empty cells (Spearman correlation $r_{s}=-0.243$, $\mathrm{n}=176, \mathrm{p}=0.0012$ ) were found. These relationships show that an increase in empty cells is connected with an increase in superparasitism by E. robusta, which affects the host and also increased parasitoid mortality.

Figures $4 \mathrm{a}, \mathrm{b}$ indicate the differences in the frequency and distribution patterns of empty cells and E. robusta larvae at two of our study areas. The average number of empty cells/gall (Fig. 4a) increased slightly with increasing gall diameter in the Belfort-Sundgau region

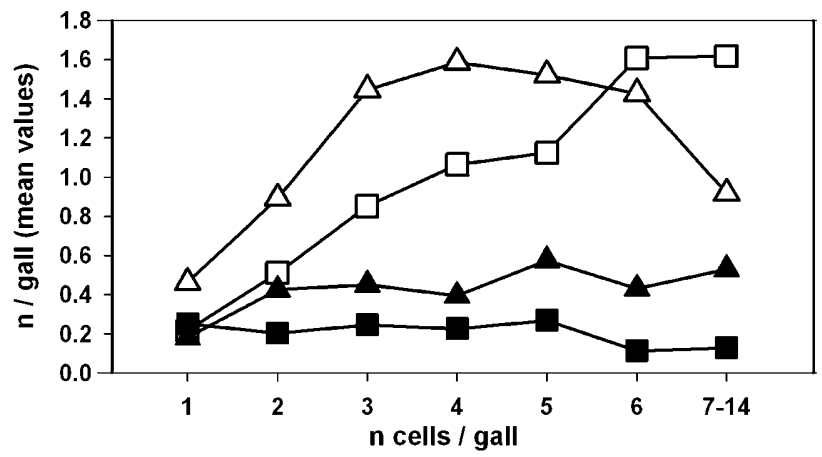

Fig. 4b. The relationships between average number of empty cells/gall (triangles), surviving E. robusta larvae/gall (squares) and gall size (= number of cells/gall), in the Bayreuth (open symbols) and the Belfort-Sundgau regions (filled symbols). 
(Kruskal-Wallis test: $\chi^{2}=66.20, \mathrm{n}=1171, \mathrm{p}<0.001$ ), whereas it declined strongly in the Bayreuth region (Kruskal-Wallis test: $\chi^{2}=44.616, \mathrm{n}=1076, \mathrm{p}<0.001$ ). The relationship between number of empty cells/gall and the gall size measured as the total number of cells/gall (Fig. 4b) is not significant in the Belfort-Sundgau region (Kruskal-Wallis test:, $\chi^{2}=8.428, \mathrm{n}=1171, \mathrm{p}=0.2084$ ), but follows a hump-backed curve in the Bayreuth region (Kruskal-Wallis test: $\chi^{2}=79.688, \mathrm{n}=1076, \mathrm{p}<0.001$ ). We assume that the different role of E. robusta and number of empty cells in the two observation regions (Figs $4 \mathrm{a}$ and $4 \mathrm{~b}$ ) is primarily due to habitat differences and the local population structure of the host.

\section{Effect of $E$. robusta and empty cells on the survival and galls of $\boldsymbol{U}$. cardui}

An analysis of the whole data set indicates that both the occurrence and frequency of $E$. robusta larvae and empty cells are good indicators of the mortality suffered by $U$. cardui larvae. The standardized partial regression coefficients (beta values) of a multiple regression with the factors: E. robusta larvae/gall, empty cells/gall and E. serratulae larvae/gall show that the predictor "empty cells" has a higher effect on the variable "survival of $U$. cardui larvae" than the numbers of E. robusta larvae/gall or the larval densities of the specialized endoparasitoid E. serratulae (Table 1). Fig. 5 shows that only in galls with no empty cells does the number of $E$. robusta larvae/gall/sample have a strong and proportional effect on the survival of $U$. cardui (Kruskal-Wallis test: $\chi^{2}=$ $26.02, \mathrm{n}=100$ samples, $\mathrm{p}<0.001)$; in gall samples with averages of 0.1 to 1 empty cell/gall the effect of $E$. robusta is distinctly weaker, but still significant (KruskalWallis test:, $\chi^{2}=76.96, \mathrm{n}=389$ samples, $\mathrm{p}<0.001$ ) and in those with more than one empty cell/gall the effect of E. robusta is statistically insignificant (Kruskal-Wallis test: $\chi^{2}=7.0, \mathrm{n}=220$ samples, $\mathrm{p}=0.1359$ ).

A multiple regression analysis of 48 gall samples (1566 galls), with gall diameter as a dependent variable, indicated that only the predictor variable "empty cells/gall" has a significant negative partial regression coefficient (beta $=-0.17424, \mathrm{t}=-5.443, \mathrm{p}<0.001$ ). For the variable E. robusta larvae/gall the beta coefficient is not significant (beta $=0.0555, \mathrm{t}=1.735, \mathrm{p}=0.083$ ). This means that the effect of $E$. robusta larvae on gall growth is predominantly mediated by the number of empty cells, not by a preference for ovipositing in smaller galls, a conclusion also drawn by Johannesen \& Seitz (2003a). Zwölfer

TABLE 1. Results of a multiple regression analysis of the effect of E. robusta larvae/gall/sample, empty cells/gall/sample and E. serratulae larvae/gall/sample on the survival of $U$. cardui larvae/gall/sample. $\mathrm{N}=705$ gall samples; dependent variable = living $U$. cardui larvae/gall/sample; multiple $\mathrm{R}^{2}=$ 0.3740 .

\begin{tabular}{lcccrc}
\hline Variable & $\mathrm{b}$ & s.e. & Beta & $\mathrm{t}$ & Sign. $\mathrm{t}$ \\
\hline empty cells & -1.05562 & 0.06595 & -0.48397 & -16.006 & 0.0000 \\
E. robusta & -0.78643 & 0.07203 & -0.32720 & -10.919 & 0.0000 \\
E. serratulae & -0.56558 & 0.07183 & -0.23804 & -7.874 & 0.0000 \\
(constant) & 3.05125 & 0.09164 & & 33.297 & 0.0000 \\
\hline
\end{tabular}

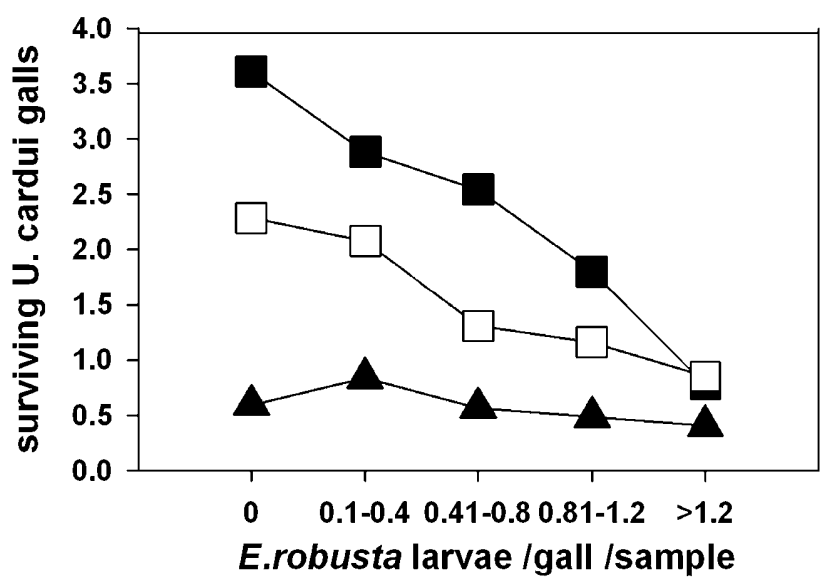

Fig. 5. Effect of the number of E. robusta larvae/gall and empty cells/gall on the average number of surviving U. carduilarvae/gall/sample. Averages of 722 gall samples (containing a total of 13790 galls) from France, Germany and Austria (col. 1972-2004). Black squares = galls without empty cells; open squares = galls with $0.1-1$ empty cell; triangles $=$ galls with $>1$ empty cell/gall.

\& Arnold-Rinehart (1994, Fig. 15.3), also record a significant inverse relationship between the number of empty cells and gall diameter.

\section{Site and host fidelity of $E$. robusta : local host specialisation?}

Once E. robusta had colonized a thistle patch with a high density of $U$. cardui galls, it showed a considerable site fidelity, even if the host population declined substantially, as was the case in our study area south of Bayreuth (Fig. 6). E. robusta females are capable of locating $U$. cardui galls even at extremely low densities. At 8 sites, where in previous years average gall densities/thistle patch were high (Fig. 6), an average of only 0.71 galls/100 thistle ramets was counted in 2004. Inspection of a total of 3517 thistle ramets inspected yielded only 25 galls, all of which contained E. robusta larvae and/or egg shells. In 4 of these samples all the $U$. cardui larvae were dead, in the other 4 samples $10 \mathrm{U}$. cardui larvae survived

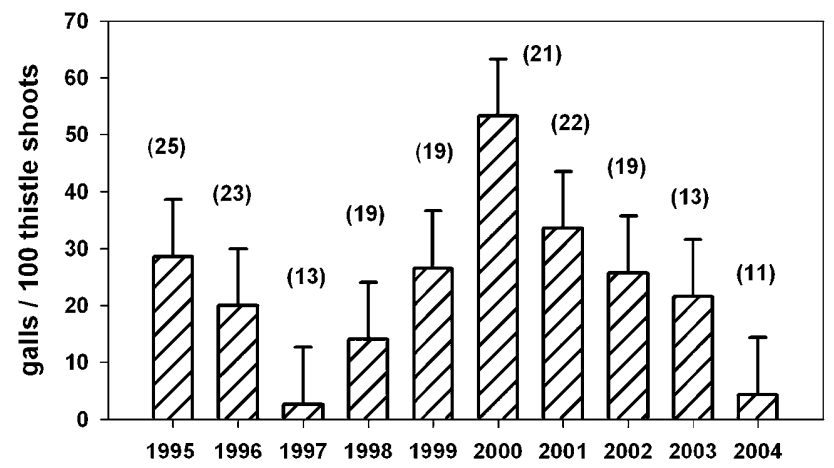

Fig. 6. The gall density of $U$. cardui (numbers of galls/100 C. arvense ramets, means and s.e.) from 1995-2004 in the study area south of Bayreuth (= Fig. 1). In parentheses: number of monitored gall populations. 
(total of E. robusta larvae $=24$, total number of empty cells $=33$ ).

In one of the thistle patches monitored annually by Zwölfer (Sophienberg, eastern slope) U. cardui gall density dropped to 18 galls/ 2009 thistle shoots, but even then every gall had been found and attacked by $E$. robusta. In 2004 a particularly high degree of superparasitism and concomitant larval competition was observed, resulting in $53 \%$ of the cells being empty and $40 \%$ of the hibernating E. robusta larvae not reaching their normal pupation size. In spite of this, another potential host of $E$. robusta at the same site, Urophora stylata (F.) galling Cirsium vulgare heads, was not attacked by E. robusta. This disregard of a potential alternative host suggests a local and temporal host specialisation of E. robusta. The fidelity to a formerly promising resource resulted in maladapted ovipositional decisions and lead into a dead end.

\section{Effect of $E$. robusta on the population dynamics of $U$. cardui}

Prior to 1980 galls of $U$. cardui were not reported from the research area south of Bayreuth. From 1977 to 1990 $U$. cardui invaded this area from the south with a total range extension of between 20-40 km (Eber \& Brandl, 1994; Zwölfer, 1994). Annual monitoring (1995 to 2004) of the galls at 32 selected thistle localities in this area (Fig. 1) yielded the data shown in Fig. 6. Except for 2 small patches all thistle populations persisted from at least 1995 to 2005 . From 1995 to 199712 U. cardui populations disappeared and the average gall density decreased from 28.6 galls $/ 100$ shoots to 2.7 galls/100 shoots. In 19986 new $U$. cardui populations appeared, in 19992 populations disappeared and 2 appeared, and in 2000 the number of $U$. cardui populations (21) and gall densities reached a new maximum. From 2001 to 200411 populations died out and gall densities decreased to a new minimum of 4.3 galls/100 shoots. In spite of using a different monitoring method Eber \& Brandl (2003) obtained analogous results in an adjacent area east of our study site (compare their Fig. 1D with our Fig. 6).

The annual records of gall densities in the Bayreuth area (Zwölfer, unpubl.) indicate periodical fluctuations. During the first years for which records of $U$. cardui in north-eastern Bavaria (1978-1980) are available, average gall densities ( $\mathrm{n}=27$ populations) were relatively low, ranging from 6.4 to 11.7 galls/100 shoots. A peak in average gall densities was observed in 1984 with 35.0 galls/100 shoots ( $n=27$ populations), and in 1990 a second peak with 33.3 galls $/ 100$ shoots $(n=115$ populations). Together with the density peaks in 1995 and 2000 mentioned above, these 4 maxima suggest large-scale fluctuations with a periodicity of 5-7 years, which are superimposed on local extinction-colonisation dynamics (Zwölfer, 1979; Seitz \& Komma, 1984; Eber \& Brandl, 1994, 1996).

Eurytoma robusta and the decline of $U$. cardui populations

Experimental field colonies of $U$. cardui established in Switzerland by Zwölfer suffered no or very little para-

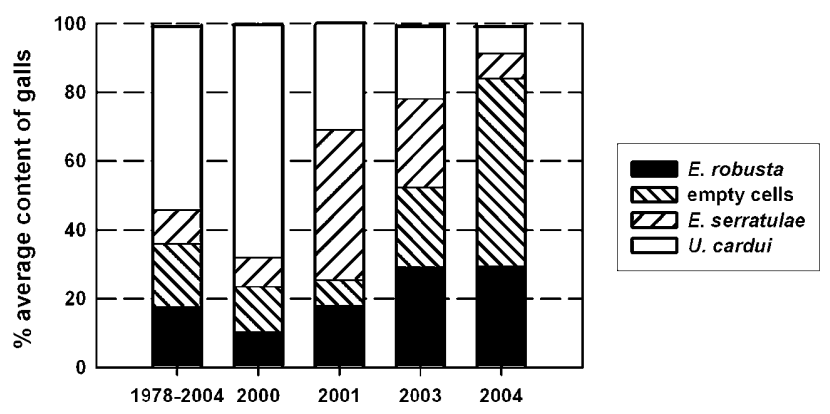

Fig. 7. The average (1978-2004) and trend (2000-2004) in the average contents of $U$. cardui galls in the study area south of Bayreuth. 1978-2004 = 222 samples with 4159 galls; $2000=12$ samples with 239 galls; $2001=4$ samples with 83 galls $(2002=$ no samples); $2003=10$ samples with 362 galls; $2004=28$ samples with 423 galls.

sitism by $E$. robusta in the first generation (Zwölfer, 1979, 1994). Of the 8 field colonies of $U$. cardui, which Zwölfer (unpubl.) established in 1994, in the study area south of Bayreuth, only 4 were attacked by E. robusta in the first year, with a low average parasitism in the first generation (mean 4.7\%, minimum 0 and maximum $12.7 \%$ ). Similarly, in 2000 when there was a peak in gall densities (Fig. 6) and high proportion of young U. cardui subpopulations, percentage of deaths due to E. robusta and empty cells was low at the Bayreuth study area (Fig. 7). With increase in age of the subpopulations attack by E. robusta and the number of empty cells/gall gradually increased and resulted in a high percentage mortality of $U$. cardui. Fig. 7 shows this trend for the years 2000-2004. It was accompanied by a strong decline in average gall density and the disappearance of many gall populations (Fig. 6).

Over all, the average percentage survival of $U$. cardui larvae in the years 1978-2004 was about 50\% in the Bayreuth region (Fig. 7). From a maximum in the year 2000 there was a steady and highly significant decline in gall densities and number of occupied patches until gall densities (Fig. 6) and percentage survival of $U$. cardui larvae reached a minimum in 2004 (Fig. 7) (Kruskal-Wallis 1-way ANOVA: $\chi^{2}=23.855, \mathrm{n}=54$ populations, $\mathrm{p}<$ 0.001; no data available for 2002). After increasing from 2000 to 2001 the populations of the monophagous endoparasitoid E. serratulae declined from 2001 to 2004 (Kruskal-Wallis 1-way ANOVA: $\chi^{2}=12.172, \mathrm{n}=42$ populations, $\mathrm{p}=0.0017)$. The number of $E$. robusta/gall from 2000 to 2004 showed a slight tendency to increase (Kruskal-Wallis 1-way ANOVA: $\chi^{2}=7.5639, \mathrm{n}=54$ populations, $\mathrm{p}=0.0557)$, but the average number of empty cells/gall increased dramatically from 2001 to 2004 (Kruskal-Wallis 1-way ANOVA: $\chi^{2}=17.105, \mathrm{n}=$ 42 populations, $\mathrm{p}=0.0002)$. Since high numbers of empty cells/gall indicate a high incidence of superparasitism and concomitant high mortality of E. robusta larvae, it is likely that few larvae of E. robusta survived and the frequency of ovipositions by this species was distinctly higher in 2004 than in 2003. A multiple regression of the values from 2001 to 2004 , with the dependent vari- 
able "living U. cardui larvae" (averages of 42 gall samples, multiple $\mathrm{R}^{2}=0.403$ ) provides standardized partial regression coefficients (beta values) of -0.4613 ( $\mathrm{p}<$ 0.001 ) for the predictor variable "empty cells", of -0.3142 ( $\mathrm{p}<0.001)$ for " $E$. robusta larvae/cell" and $-0.2892(\mathrm{p}<0.001)$ for the variable " $E$. serratulae larvae/cell". Thus, "empty cells" attributed to E. robusta (Fig. 7) is the most important factor causing the decline of the $U$. cardui populations in the study area south of Bayreuth (Fig. 6).

\section{Habitat differences and the effect of $E$. robusta in the different study areas}

In 2004 the decline of the populations in the area south of Bayreuth contrasted strikingly with the performance of the populations of $U$. cardui in the Belfort-Sundgau region and Upper Rhine Valley (Figs 3, 4a,b). For the latter two regions, data for 19 years, 489 gall samples and a total of 9076 dissected $U$. cardui galls, collected between 1970 and 2003, are available. They suggest relatively stable populations, as Zwölfer (1994) records an average of $95 \%$ annual survival in these populations. Average gall contents were 1.622 surviving $U$. cardui larvae/gall, 0.497 E. robusta larvae/gall and 0.676 empty cells/gall. The 22 samples collected in 2004 in the Belfort-Sundgau region (total of 250 galls) yielded comparable values for live $U$. cardui larvae (1.50), E. robusta larvae (0.61) and empty cells (0.77). Corresponding data (2004) for the study area south of Bayreuth (32 samples with 480 galls) were $0.38,0.93$, and 1.83. Mann-Whitney $\mathrm{U}$ tests revealed significant differences in the numbers of surviving $U$. cardui larvae and empty cells $(\mathrm{p}<0.001)$, but only weakly significant differences in numbers of $E$. robusta $(\mathrm{p}=0.0366)$. Thus, while similar mortality factors (E. robusta, empty cells) were recorded in all regions, the number of empty cells (and hence superparasitism by E. robusta) was much higher in the area south of Bayreuth (Fig. 4a,b).

This result accords with the earlier study of Schlumprecht (1990) who found (1985-1989) fewer E. robusta larvae per gall (0.2475 larvae/gall) in the floodplain forests of the Upper Rhine Valley than in north-east Bavaria (0.6837 larvae/gall) (Kruskal-Wallis test: $\mathrm{n}=94, \mathrm{p}<$ 0.001 ) and reports a distinctly lower fluctuation in larval densities of $U$. cardui in the Upper Rhine Valley (s.e./mean ratio $=0.1214, \mathrm{n}=44$ populations) than occurs in the Bayreuth area (s.e./mean ratio $=0.2031, \mathrm{n}=17$ populations).

Comparing the two sampling regions we conclude that the peculiarities of the habitats and the different distribution patterns of $C$. arvense are mainly responsible for the different impact and ecological role of E. robusta. In the Upper Rhine Valley Schlumprecht's and our samples originated from scattered thistle patches in riverine forests and in the Belfort-Sundgau region from clearings in large forests, whereas in the study area south of Bayreuth most of the samples were collected from abandoned meadows and other types of open fallow land. In this type of habitat many of the thistle patches are highly aggregated with high shoot densities (more than 20 ramets per $\mathrm{m}^{2}$ ), whereas the shoot densities of $C$. arvense in thistle patches inside riverine and other large forests are usually much lower.

The influence of habitat is also recognizable in the Bayreuth study area, where the large Veldenstein forest (Fig. 1) contrasts with the more open landscape to the north where the subpopulations of $U$. cardui are short-lived. When the search for $U$. cardui galls started in the Bayreuth region in 1979, the first $U$. cardui populations were detected in the Veldenstein forest (Zwölfer, 1994) and in this forest area (marked in Fig. 1 by a triangle) is the population that has survived for the longest period $(17+$ $\mathrm{x}$ years). Interestingly, the average number of surviving U. cardui larvae/gall (0.689) was greater here in 2004/5 than in the populations in the open habitats at the Bayreuth study area $(0.224)\left(\chi^{2}=86.78\right.$, df $\left.1, p<0.001\right)$. This accords with results of Schlumprecht (1990), who found a statistically significant preference of E. robusta for galls thistle patches fully exposed to the sun. In a large thistle field he recorded a gradient of $62 \%$ parasitism by $E$. robusta of galls fully exposed to the sun to $0 \%$ for those in the shade.

\section{DISCUSSION}

\section{Eurytoma robusta: a poorly adapted parasitoid of $\boldsymbol{U}$. cardui}

A striking feature of E. robusta is that it is relatively poorly adapted to parasitising $U$. cardui. E. robusta has a broad host range, unlike the monophagous parasitoid $E$. serratulae, and its oviposition period is often not well synchronized with the gall development of $U$. cardui (Zwölfer et al., in prep.), as previously reported by Varley (1947) for an E. robusta population attacking galls of Urophora jaceana Hering in knapweed flower heads. E. robusta females prefer $U$. cardui galls containing thirdinstar larvae, but are unable to assess the optimal $U$. cardui gall sizes for oviposition (Zwölfer et al., in prep.), a fact, which Weis et al. (1985) reports also for Eurytoma gigantea Walsh parasitising Eurosta solidaginis (Fitch). Another symptom of this is frequent superparasitism and the occurrence of empty cells, which occurs also in other Urophora spp. (U. stylata, U. solstitialis (L.), (Zwölfer and Arnold-Rinehart, 1994); U. jaceana (Varley, 1941, 1947; Dempster et al., 1995). The occurrence of empty cells is also described for Eurytoma longavena Bugbee in galls of Diplolepis (Shorthouse, 1973). We interpret this poorly adapted oviposition behaviour as the consequence of "Jack of all trades is master of none" (Rosenzweig et al., 1987).

\section{Local and temporal host specialisation?}

There is a time lag in the establishment of E. robusta in experimentally established field populations of $U$. cardui (Figs 13, 14 in Zwölfer, 1979). It took 3-5 years for $E$. robusta to build up high population densities with concomitant superparasitism, egg mortality and empty cells. In his study of the development of parasitism of $U$. cardui in Finland Vikberg (2005) found that it took 7 years for E. robusta to appear in the parasitoid complex, but then it became the dominant species. Comparative analyses of 
the genetic structure of $U$. cardui and E. robusta populations in Denmark and northern Germany by Johannesen $\&$ Seitz (2003b) support this delay in the development of parasitism.

In our study area at least some E. robusta females, which developed in formerly dense $U$. cardui populations, must have stayed in the thistle patches and searched for isolated galls, even after the gall densities had drastically declined. In these thistle patches $E$. robusta females are good at finding even the last scattered host galls. Varley (1947) also observed a highly developed host locating ability in a E. robusta population foraging for $U$. jaceana galls in knapweed heads. Our field observations, as well as Vikberg's (2005) data and the study on the population genetics of E. robusta by Johannesen \& Seitz (2003b) suggest the same conclusion: In spite of a generally wide host range (Vet \& Dicke, 1992), local E. robusta populations, once established in a $U$. cardui patch, can develop a high host fidelity. Such local host specialisation is recorded by Kankare et al. (2005) in members of the parasitoid genus Cotesia and Kraaijeveld (2004) describes a similar phenomenon in the parasitoid Asobara tabida. The mechanisms involved are unknown. Results of experiments (e.g. Bogahawatte \& Van Emden, 1996) indicate that host-plant odours or other cues encountered by the emerging parasitoid adults (Van Emden et al., 1996) can trigger host preference in parasitoid females.

\section{Regional differences in the population dynamics of $E$. robusta and $U$. cardui}

The overexploitation by E. robusta of a strongly declining resource destroyed the experimental U. cardui colonies set up by Zwölfer $(1979,1994)$ and is the main cause of the relatively short period of survival of most $U$. cardui colonies in the study area south of Bayreuth. Also Eber \& Brandl $(1994,2003)$ report that E. robusta is the main mortality factor in their research area in northeastern Bavaria, where gall populations drastically decreased from 2900 galls in 1995 to 150 galls in 1997. It is interesting that the impact of E. robusta is much less severe in the Sundgau-Belfort region and upper Rhine Valley, an observation already reported by Schlumprecht (1990) and Zwölfer (1994).

The dynamics of most $U$. cardui populations in the Bayreuth region are characterized by local range extensions, temporary high densities and local declines in abundance and extinctions of subpopulations, following more or less distinct cycles with periods of 5-7 years (Fig. 6). In north-eastern Bavaria many thistle stands develop on abandoned farm land, or in similar habitats, and have a considerable turnover in space and time (Eber $\&$ Brandl, 2003). Potential alternative host species for $E$. robusta such as knapweed or spear thistle occur frequently there and many thistle patches are fully exposed to the sun, which are the favoured habitats of host searching E. robusta (Schlumprecht, 1990). In contrast, the great majority of thistle patches monitored by us in the Belfort-Sundgau region and Upper Rhine Valley were in riverine forests, on river banks, at forest edges, in forest clearings or marshy grass land, mostly at altitudes below $400 \mathrm{~m}$. These loose networks of host plant patches support relatively stable $U$. cardui populations and are a source of flies that establish short-lived peripheral subpopulations associated with small, ephemeral thistle patches or thistle stands at sites at higher elevations. This is supported by the significant negative correlation $(\mathrm{r}=-$ $0.54, \mathrm{p}<0.001$ ) between average size of $U$. cardui populations and altitude above sea level (Zwölfer, 1994).

We assume that the $C$. arvense - $U$. cardui system in the Veldenstein forest south of Bayreuth (Fig. 1) is to some extent comparable to that in the Sundgau and floodplains of the Upper Rhine Valley. In the forest and river bank habitats, which do not support the dense aggregations of thistles characteristic of abandoned agricultural areas and are more shaded, E. robusta is not able to achieve detrimentally high densities exploiting local $U$. cardui populations. Why there are unstable nonequilibrium population systems in the Bayreuth area and relatively stable source-sink systems in the riverine forests of the Upper Rhine Valley and Belfort-Sundgau region needs to be resolved. Possible factors are the differences in the vegetation patterns, the size and structure of the thistle stands, the microclimate of the habitat (Rotheray, 1986; Peschken \& Derby, 1997) and the altitude above sea level.

ACKNOWLEDGEMENTS. This study is dedicated to Professor emeritus Dr. Hubert Pschorn-Walcher (Neulengbach, Austria) on the occasion of his 80th birthday. His work has provided important new insights into the biology of parasitoids and the structure of parasitoid-host systems. We gratefully acknowledge the support of the German Research Foundation (Graduiertenkolleg No. 678 "Bedeutung von Wirk- und Signalstoffen für Tiere - von der Struktur zur Funktion im Ökosystem”).

\section{REFERENCES}

Bogahawatte C.N.L. \& Van Emden H.F. 1996: The influence of the host plant of diamond-back moth (Plutella xylostella) on the plant preferences of its parasitoid Cotesia plutellae in Sri Lanka. Physiol. Entomol. 21: 93-96.

Claridge M.F. 1961: Biological observations on some eurytomid (Hym. Chalicidoidea) parasites associated with Compositae, and some taxonomic implications. Proc. R. Entomol. Soc. London (A) 36: 153-158.

Dempster J.P., AtKinson D.A. \& Cheesman O.D. 1995: The spatial population dynamics of insects exploiting a patchy food resource. Oecologia 104: 340-353.

Eber S. \& BRANDL R. 1994: Ecological and genetic spatial patterns of Urophora cardui (Diptera: Tephritidae) as evidence for population structure and biogeographical processes. $J$. Anim. Ecol. 63: 187-199.

Eber S. \& BRANDL R. 1996: Metapopulation dynamics of the tephritid fly Urophora cardui: an evaluation of incidencefunction model assumption with field data. J. Anim. Ecol. 65: 621-630.

Eber S. \& BRANDL R. 2003: Regional patch dynamics of the weed Cirsium arvense, and possible implications for plant animal interactions. J. Veg. Sci. 14: 259-266.

Frenzel M., Eber S., Klotz S. \& Brandl R. 2000: Ecological comparisons across geographical distributions: the thistle gall fly Urophora cardui (Diptera: Tephritidae) on different Cirsium hosts. Eur. J. Entomol. 97: 183-189. 
Johannesen J. \& Seitz A. 2003a: Larval distributions of the ectoparasitoid wasp Eurytoma robusta relative to the host tephritid gall fly Urophora cardui. Entomol. Exp. Appl. 107: $47-55$.

JohANNESEN J. \& SeITZ A. 2003b: Comparative population genetic structures of the fruit fly Urophora cardui and its primary parasitoid Eurytoma robusta. Entomol. Exp. Appl. 107: 149-157.

Kankare M., Stefanescu C., van Nouhuys S. \& Shaw M.R. 2005: Host specialization by Cotesia wasps (Hymenoptera: Braconidae) parasitizing species-rich Melitaeini (Lepidoptera: Nymphalidae) communities in north-eastern Spain. Biol. J. Linn. Soc. 86: 45-65.

KraAiJeveld A.R. 2004: Experimental evolution in hostparasitoid interactions. In Ehler L E., Sforza R. \& Mateille T. (eds): Genetics, Evolution and Biological Control. CABI International, Wallingford, pp. 163-181.

Lalonde R.G. \& Shorthouse J.D. 1984: Developmental morphology of the gall of Urophora cardui (Diptera, Tephritidae) in the stems of Canada thistle (Cirsium arvense). Can. J. Botany 62: 1372-1384.

PeschKen D.P. \& Derby J.L. 1997: Establishment of Urophora cardui (Diptera: Tephritidae) on Canada Thistle, Cirsium arvense (Asteraceae), and colony development in relation to habitat and parasitoids in Canada.. Ecol. Stud. 130: 53-66.

RotherAy G.E. 1986: Effect of moisture on emergence of Urophora cardui (L.) (Diptera: Tephritidae) from its gall on Cirsium arvense (L.). Entomol. Gaz. 37: 41-44.

Rosenzweig M.L., Brown J.S. \& Vincent T.L. 1987: Red queens and ESS: the coevolution of evolutionary rates. Evol. Ecol. 1: 59-94.

SCHLUMPRECHT H. 1990: Untersuchungen zur Populationsökologie des Phytophagen-Parasitoid-Systems von Urophora cardui L. (Diptera: Tephritidae). PhD Thesis, University of Bayreuth, 143 pp.

Shorthouse J.D. 1973: The insect community associated with rose galls of Diplolepis polita (Cynipidae, Hymenoptera). Quest. Entomol. 9: 55-98.

Seitz A. \& Komma M. 1984: Genetic polymorphism and its ecological background in tephritid populations (Diptera: Tephritidae). In Wöhrmann K. \& Loeschke V. (eds): Population Biology and Evolution. Springer, Heidelberg, pp. 143-158.

Van Emden H.F., Sponagl B., Wagner E., Baker T., Ganguly S. \& DouloumpaKa S. 1996: Hopkins' "host selection principle", another nail in its coffin. Physiol. Entomol. 21: 325-328.
VARLEY G.C. 1941: On the search for hosts and the egg distribution of some chalcid parasites of the knapweed gall-fly. Parasitology 33: 47-66.

VARLEY G.C. 1947: The natural control of population balance in the knapweed gall-fly (Urophora jaceana). J. Anim. Ecol. 16: 139-187.

Vet L.E. \& Dicke M. 1992: Ecology of infochemical use by natural enemies in a tritrophic context. Annu. Rev. Entomol. 37: $141-72$.

VIKBERG V. 2005: The thistle stem gall-fly (Urophora cardui) and its chalcidoid parasitoids in southern Finland (Hymenoptera: Chalcidoidea). Sahlbergia 10: 30-49 [in Finish, with English abstr.].

Weis A.E., Abrahamson W.G. \& McCrea K.D. 1985 Host gall size and oviposition success by the parasitoid Eurytoma gigantea. Ecol. Entomol. 10: 341-348.

ZwÖLFER H. 1979: Strategies and counterstrategies in insect population systems competing for space and food in flower heads and plant galls. Fortschr. Zool. 25: 331-353.

ZWÖLFER H. 1994: Structure and biomass transfer in food webs: stability, fluctuations, and network control. In Schulze E.-D. (ed.): Flux Control in Biological Systems from Enzymes to Populations and Ecosystems. Academic Press, San Diego, pp. 365-419.

Zwölfer H. \& ARnold-Rinehart J. 1993: The evolution of interactions and diversity in plant-insect systems. The Urophora-Eurytoma food web in galls on Palearctic Cardueae. Ecological Studies. Vol. 99. Springer, Berlin, Heidelberg, New York, pp. 211-233.

ZwÖLFER H. \& ARNold-Rinehart J. 1994: Parasitoids as a driving force in the evolution of gall size of Urophora on Cardueae hosts. In Williams M.A.J. (ed.): Plant Galls. Systematics Association Special Volume No. 49. Clarendon Press, Oxford, pp. 245-57.

ZwÖLFER H. \& Schlumprecht H. 1993: Resource utilization, population structures and population dynamics of Urophora cardui L. (Dipt.: Tephritidae), a gall former on stems of Cirsium arvense. In den Boer P.J., Mols M. \& Szysko J. (eds): Dynamics of Populations, Proceedings of the meeting on population problems, Smolarnia, Poland, 9-15 Sept. 1992, Agricultural University, Warsaw, pp. 55-58.

Received May 17, 2006; revised and accepted November 13, 2006 